\title{
Die ander opsie: \\ Kohlbrugge - Hoedemaker - Barth
}

D J C van Wyk (sr)

Tydelik-deeltydse dosent: Departement Godsdiens- en Sendingwetenskap

Universiteit van Pretoria

\begin{abstract}
Another option: Kohlbrugge - Hoedemaker - Barth

The focus of this article is on the nature of the theological ethos of the Nederduitsch Hervormde Kerk. It is argued that the ethical direction taken by Dutch theology in the late nineteenth and early twentieth centuries had little influence on the early theological training of the Nederduitch Hervormde Kerk and the theology of the Nederduitch Hervormde Kerk in general. Specifically, the article aims at demonstrating that the theology of the Nederduitsch Hervormde Kerk has been influenced by particularly the Dutch theologians Kohlbrugge, Hoedemaker and the later confessionals as well as by the German theologian Karl Barth. Attention is also given to Hoedemaker's position with regard to historical criticism and the accusation that he was a fundamentalist.
\end{abstract}

\section{INLEIDING}

In 'n vroeëre uitgawe van Hervormde Teologiese Studies (Van Wyk 1998:245-263) is na aanleiding van $\mathbf{J}$ A Loader se omvattende navorsing oor die etiese teologie krities gekyk na die bevinding waartoe hy met betrekking tot dié teologiese rigting se invloed op die Nederduitsch Hervormde Kerk gekom het. Dié bevinding was naamlik dat die etiese rigting in die Nederlandse teologie van die laaste helfte van die negentiende en begin twintigste eeu, indien nie die belangrikste agtergrond nie, dan tog een van die belangrikste invloede in veral die vroeë stadium van 'n Hervormde teologiese opleiding in Suid-Afrika was.

$\mathrm{Na}$ deeglike kennisname en kritiese ontleding van die siening van Loader, is in bogenoemde artikel tot 'n paar konklusies gekom.

* Dat die uitdrukking 'die waarheid is eties' iets wou sê oor die etiese rigting in Nederland se waarheidsbegrip, lyk seker. Dat die opvatting oor waarheid, naamlik dat dit geleer word in die ontmoeting met God, kenmerkend is van die Hervormde 
Kerk se waarheidsbeskouing, is ook korrek. Maar die konklusie van Loader dat dit via die etiese teologie gekom het, word betwyfel. Sou dit ook waar wees, is die verdere konklusies oor sterk invloed van die etiese rigting in ons eie teologie wat daarop gebou word, twyfelagtig. Dit kom voor of vir baie min verteenwoordigers uit die etiese rigting self dit werklik oor die waarheidsbeskouing gegaan het. Onder dié vlag het baie vreemde goed saamgevaar: subjektivisme, indiwidualisme, sintesedrang, piëtisme, onkerksheid; alles teologiese familietrekke wat wesensvreemd is aan die Nederduitsch Hervormde Kerk en die teologie wat in die Hervormde Kerk beoefen word.

* Dat, hoewel daar op die klank af soms sterk ooreenkomste tussen die etiese rigting en die teologie, soos in die teologiese opleiding aan die Universiteit van Pretoria (Afd A) en Hervormde kerklike kringe beoefen, vermoed kan word, die etiese teologie tog wesensvreemd is aan die Nederduitsch Hervormde Kerk se teologiese inhoude, klimaat en gedagtewêreld.

* Die etiese rigting het ook nie, soos Loader en ook ander beweer, aan invloed en bekendheid getaan omdat dit deel van ons teologiese denke geword het, of vanweë die wyd geskakeerdheid en daarom moeilik definieerbaarheid daarvan nie. Die werklike rede vir dié verlies aan verdere invloed was dat dit so met wysgerige stromings geïdentifiseer het, dat dit gedoem was om saam met dié stromings te verdwyn.

* 'n Ander faset van die etiese teologie waar rondom daar ernstige vrae bestaan, is die houding en gesindheid rondom die kerk en die nood van die kerk in dié tyd. Vir baie van die etiese teoloẻ het dit meer gegaan om die ontwikkeling van sedelik hoogstaande persoonlikhede, die eie innerlike geestelike lewe, met min aandag en liefde vir die kerk. Met die uitsondering van J H Gunning (jr) en dan ook eers in sy latere beïnvloeding deur Hoedemaker, word geen name van etiese teoloë in die titaniese en eensame stryd wat Hoedemaker in dié tyd vir kerkherstel voer, aangetref nie (Van Wyk 1998:257). Loader oorweeg nie dié aspek in sy waardering van die etiese teologie nie.

* Dit wil daarom voorkom of Loader die etiese teologie of eensydig beoordeel of in elk geval die invloed daarvan op die teologiese denke in die Nederduitsch Hervormde Kerk sterk oorspan. 
Dié oorspanning word veroorsaak deur Loader se begeerte en poging om na analogie van die Nederlandse situasie, die invloed van die etiese teoloë se waarheidsopvatting in die Hervormde teologie hier, as derde opsie en heelmiddel in wat hy noem 'n teologiese twis, aan te beveel.

Sy betoog cortuig egter nie. Dat daar in die Hervormde Kerk die afgelope jare 'n lewendige debat was rondom die belydenis, waarheidsbeskouing en ook nog ander sake is waar. Maar om te praat van ' $n$ twis, is oordrewe. In die proses dring hy aan A D Pont en A G van Aarde 'n proposisionele waarheidsbeskouing op wat sterk geforseerd voorkom. Dit laat in elk geval ook nie reg geskied aan dié teoloë se werklike waarheidsbeskouings nie (kyk bv Van Aarde 1995:41vv).

In wat in hierdie artikel verder volg, sal gepoog word om 'n ander teologiese klimaat en ontwikkelingslyn as vernaamste agtergrond van Hervormde teologie en opleiding in Suid-Afrika te suggereer, naamlik die lyn vanaf Kohlbrugge na Hoedemaker, na Barth. In dié proses sal ingegaan word op die beskuldigings van fundamentalisme teen Hoedemaker asook op sy werklike posisie ten opsigte van die historiese kritiek.

Dit is opmerklik dat al drie genoemde teoloe in en vir hulle tyd soms radikaal was in hulle teologiese uitsprake. By al drie sou die felheid, wat nie net radikaal nie maar soms ook eensydig kon voorkom, verklaar kan word uit die besef en erkenning dat in ' $n$ tydsgewrig waarin alles en almal besig is om willoos en koersloos saam af te dryf in 'n stroom van teologiese modernisme en vrysinnigheid, of die teenreaksies naamlik ortodoksisme en konfessionalisme, dit slegs met 'n baie kragtige ruk van die roer is dat verandering en koerswending aangebring kon word.

By sowel Kohlbrugge as Hoedemaker en Barth kom 'n kragtigheid en selfstandigheid in teologiese denke en uitsprake aan die lig wat dit eenvoudig onmoontlik gemaak het dat hulle ooit meelopers van enige persoon, groep of party kon word. Karl Barth het hom 'n keer in kritiese selfontleding afgevra of alle sintetiese krag dan aan sy lewenswerk ontbreek; omdat dit vir hom voorgekom het dat daar van sy werk en denke ' $n$ bepaalde eksplosiewe of in elk geval sentrifugale werking uitgaan. In die tien jaar na die Eerste Wêreldoorlog het hy en 'n hele paar ander teoloē, waaronder Friedrich Gogarten, Emil Brunner en later ook Rudolf Bultmann gemeen dat hulle mekaar gevind het in wat hulle gedink het en wou doen. Maar mettertyd het alles in rook opgegaan ... en moes hy van almal afskeid neem (Kupisch 1972:97). Hierop word later nog weer teruggekom. Maar veel van hierdie eensaamheid van weg en stryd het ook die lewensloop van Kohlbrugge en Hoedemaker gestempel. 


\section{HERMANN FRIEDRICH KOHLBRUGGE 1803-1875}

Dit mag die moeite werd wees om die lewensloop en teologiese werk van H F Kohlbrugge in die verband van hierdie studie en vir die huidige tydsgewing weer 'n keer aan die vergetelheid te ontruk. Die feit dat soveel prominente teoloë wat sterk invloed op die teologie van die Nederduitsch Hervormde Kerk uitgeoefen het, telkens hulle verwantskap met Kohlbrugge aangevoel en verklaar het, ondersteun die belang van so 'n onderneming. In hierdie verband word gedink aan onder andere Karl Barth, K H Miskotte en Th L Haitjema. Daarop sal later teruggekom word.

\subsection{Lewenskets}

Net deur sy veelbewoë lewensgang na te gaan, word 'n deel van Kohlbrugge se teologiese insigte reeds duidelik. Hy het fel gestry teen die modernisme van die negentiende eeu, maar ook teen alle vorms van seperatisme, soos die afskeiding van 1834; ook teen die Réveil, hoewel hy met baie van die leidsmanne uit dié rigting kontak en simpatie gehad het. Hy het veral in die latere fase van sy lewe, ewe skerp alle vorms van valse vroomheid en ortodoksisme ontmasker.

Kohlbrugge is in 1803 gebore uit 'n Duitse vader en Nederlandse moeder wat hulle in Amsterdam vestig en daar ' $n$ besigheid bedryf. Reeds in sy eerste jare, soos telkens in sy latere lewe, moes hy die swaar van bittere armoede leer ken en verduur. Hy lê belydenis van geloof af in die Hersteld Evangelisch-Lutherse Kerk in Amsterdam waartoe sy ouers behoort. Na aanvanklike teologiese studie word hy in hierdie kerk proponent en hulpprediker. By sy vader se sterfbed le hy 'n belofte af om hom as doktor in die teologie te bekwaam.

As hulpprediker verkondig hy op kragtige wyse al die ou geloofswaarhede oor die mens se volkome ellende, berou en bekering, die gevare van doodse regsinnigheid, noodsaaklikheid van 'n lewende geloof, weergeboorte, die regverdiging van die sondaar deur geloof alleen en die onveranderlike trou van God (kyk Loos 1948:15). Dit bring hom baie gou in botsing met een van sy medeleraars, D R Uckerman, wat in sy prediking vrye baan aan die neologie gegee het. Die Hersteld Evangelisch-Lutherse Kerk het in 1791 van die Evangelisch-Lutherse Kerk afgeskei as gevolg van die daar heersende rasionalisme. Maar ook in dié afgeskeie kerk het die heersende tydgees van oppervlakkige moralisme spoedig deurgedring.

Kohlbrugge dien ' $n$ beswaarskrif teen Uckerman by die kerkraad in na aanleiding van 'n preek waarin laasgenoemde al die ou geloofswaarhede verswyg of verloën. Die groot meerderheid van die kerkraad kies die kant van Uckerman, waarop Kohlbrugge, na weiering om sy klag van kettery terug te trek, as hulpprediker geskors word, sy 
traktement verloor en opnuut bittere armoede verduur. Hy vertrek nou na Utrecht waar hy sy teologiese studie voortsit en in 1829 cum laude promoveer met 'n verhandeling oor Psalm 45.

Kohlbrugge's dissertasie is een machtige aanval op het liberalisme en deze aanval is meesterlijk opgezet. Wij worden voortdurend herinnerd aan wat in onze dagen manne als Karl Barth en Wilhelm Vischer.... leeren.

(Loos 1948:17)

Kohlbrugge het 'n keer gesê dat hy sonder die kansel en sonder die prediking nie kan leef nie. Dit sou nie lank duur nie of die kansel sou hom 'n tweede keer geweier word. Hy tree intussen gedurende 1829 in die huwelik met Catharina Louise Engelbert.

Gedurende die jare 1826-1833 het daar in die teologiese denke van Kohlbrugge 'n radikale ontwikkeling plaasgevind. Gedurende sy aanvanklike studiejare het hy hom intens besig gehou met 'n studie van die klassieke poësie en filosofie. Maar die studie van die Oosterse tale het hom die meeste geboei. Hy maak ook 'n grondige studie van die mistiek.

In 1826 kom sy vader te sterwe. Te midde van verskriklike armoede en vol innerlike skepsis en stryd kom daar in dieselfde jaar 'n groot omkeer in sy lewe. Hy praat later daarvan as 'n eerste bekering, toe die almagtige God hom in sy groot genade en deur die Heilige Gees kragdadig tot God getrek het. Dié eerste bekering maak 'n einde aan 'n periode van twyfel en filosofiese spekulasie. Hy lê hom nou toe op ' $n$ intense studie van die Wet en die beoefening van vroomheid. Na 1833 sou hy met 'n kritiese oog terugkyk op hierdie jare van wettiese strewe na heiligheid: In 1826 het God hom van sy twyfel bekeer; in 1833 het God hom van sy bekering en vroomheid bekeer.

Na sy huwelik in 1829 vestig Kohlbrugge hom met sy vrou in Utrecht. Uitgebreide studie oor die Ou Testament, veral die profete, volg nou; ook van die Romeine brief, Calvyn en Olevianus. Hy kry al skerper insig in die vrye verkiesing van God en die regverdiging van sondaars uit genade. Dit maak hom al meer gereformeerd in sy cortuigings. Dit, saam met sy hartstogtelike liefde vir die Nederlandse volk en geskiedenis laat hom al sterker aangetrokke voel tot die Nederlandse Hervormde Kerk; tot dié mense wat God God wil laat wees in alles, en wat in diep afhanklikheid van God se welbehae forse lyne trek, wil hy kerklik behoort (Haitjema 1953:127).

In Utrecht doen hy in 1830 aansoek om lidmaatskap van die Hervormde Kerk vir hom en sy vrou. Die kerkraad van Utrecht vra 'n bewys van goeie sedelike gedrag van 
die Lutherse kerkraad in Amsterdam aan. Dit word geweier. Na 'n sloerdery van bykans drie jaar waarin die sinode en provinsiale kerkbesture van Utrecht en NoordHolland betrokke raak, word die aansoek afgewys. Sy konflik met Uckerman, die sterk anti-liberalistiese inhoud van sy dissertasie en die bekendheid wat hy as gereformeerde prediker geniet het, het sy lidmaatskap van die Nederlandse Hervormde Kerk ongewens gemaak. Hy word herken as potensiële onrusstoker. In lyn met die gees van die tyd sê 'n predikant in dié tyd vir Kohlbrugge: Ons moet rus hê in ons kerk, rus moet ons hề (kyk Loos 1948:22).

Gelyktydig met die afwysing van Kohlbrugge se aansoek om lidmaatskap, neem die sinode besluite tot verskerping van toelating tot die proponentseksamen. Daardeur is die pad na die predikantsamp vir hom afgesny. Ongeag dié tragiese verloop van sake sou straks, tydens die afskeiding van 1834, blyk hoe onkreukbaar Kohlbrugge in sy liefde en trou aan die gereformeerde geloofswaarhede, die Nederlandse Hervormde Kerk asook in sy prinsipiële afwysing van alle seperatisme was.

In 1833 sterf sy vrou aan tering. Na dié smart en ook op grond van eie swak gesondheid, reis hy in die somer van dié jaar na die Rynland in Duitsland waar hy met hartlikheid deur vriende in Wuppertal ontvang word. Hier volg straks die gebeure waarna hy altyd as sy tweede bekering sou verwys.

In die destydse, deur rasionalisme verwoeste kerklike lewe in Duitsland, was Wuppertal 'n oase. Hier bloei 'n kragtige kerklike en geestelike lewe, maar ook allerlei vorms van aktivisme, werkheiligheid, piētisme en opwekkingsbewegings.

As gas van G P Krummacher preek Kohlbrugge in Julie van 1833 in die Alte Reformierte Kirche van Elberfeld. In sy voorbereiding van Romeine 7:14 breek daar vir hom opeens helder, nuwe lig deur. Aanvanklik het hy dié teks ook nog gelees as: Ek is vleeslik verkoop onder die sonde; met ander woorde, sover as wat die mens vleeslik is, is hy verkoop onder die sonde. Die implikasie is dan dat sover as wat die mens geestelik, weergebore is, is hy vry van die sonde. In die weergebore mens is daar dus twee beginsels, vlees en gees. Maar nou breek by Kohlbrugge kragtig oortuigings deur wat al lankal gesluimer het. Hy sien raak dat die teks anders gelees moet word: ek is vleeslik, verkoop onder die sonde. Met ander woorde Paulus bedoel in werklikheid dat ook die weergebore, bekeerde mens vleeslik is en verkoop is onder die sonde. Ook al sy werke is vleeslik en het geen verdienste voor God nie. Alle vorms van wettiese vroomheid, ook sy eie, beskou Kohlbrugge nou in kritiese lig. Ons moet ophou om heil te soek in die Wet, in heiligheid en vroomheid. Ons is vleeslik en wie vleeslik is, kan God nie behaag nie. Ons moet na Christus toe, ons moet alles in Hom soek. In gemeenskap met God leer ons die ware heiligmaking ken. Paulus sê nie: ek het vordering gemaak nie. Nee, tot ergernis van die Fariseër in hom sê hy: ek is vleeslik (Rasker 
1974:104). Weg dus met alle pogings om self ook iets te doen. Dit is 'n dwaling om te meen die heiliging is die mens se saak. Christus maak ons heilig. God red sondaars, nie heiliges nie. Kohlbrugge sou later sê dat sy eerste bekering (1826) hom van skeptikus tot vrome gemaak het. Sy tweede bekering (1833) het hom van vrome tot goddelose gemaak; goddelose wat deur God in sy vrye genade regverdig gemaak word (Loos 1948:25). Hierdie radikale omkeer sou die prediking en teologie van Kohlbrugge stempel tot aan die einde van sy lewe. Dit sou verwydering bring van die manne van die Réveil en die afskeiding van 1834.

Haitjema (1953:128) bestempel die frontverlegging wat in hierdie preek by Kohlbrugge voltrek word, as 'n wending tot geloofsaaklikheid. - Dit is ook 'n wending tot geloofskritisisme wat vergelyk kan word met die wending by Karl Barth in die tweede uitgawe van sy Romeine-kommentaar.

Die preek van Kohlbrugge is gedruk en was spoedig uitverkoop. Dit het groot indruk gemaak, maar wek ook hewige verset veral uit metodistiese en piëtistiese kringe. Saam met twee ander preke verskyn dit as Gastpredigten in druk. Kohlbrugge doen nou aansoek om toelating tot die predikantsamp in die Rynland. Tydens 'n ondersoek word die hele Amsterdamse geskiedenis weer opgerakel. Hy word verdink van antinomisme en dit alles, saam met sy 'ergerlike' uitsprake oor sonde en genade, lei daartoe dat die toegang tot die kansel hom 'n derde keer geweier word. Ook word prediking op enige kansel in die Rynland hom verbied. Hy keer terug na Nederland en gaan woon in Utrecht. 'n Tweede huwelik kon nie kerklik bevestig word nie, omdat geen predikant daartoe bereid was nie.

In 1845 reis Kohlbrugge weer 'n keer na Duitsland in 'n poging om van swak gesondheid te herstel. Hy kom in aanraking met'n groep gereformeerdes wat in verset was teen die vereniging (Union) wat koning Friedrich Wilhelm III van Pruise aan die Lutherane en gereformeerdes opgele het. Na aanvanklike weiering om op uitnodigings uit die oord in te gaan, word hy uiteindelik tog lidmaat van die Reformierte Gemeinde in Elberfeld. In 1847 word, na goedkeuring van die regering in Berlyn, in Elberfeld 'n gereformeerde gemeente gestig wat onafhanklik van die landskerk en die staat sou staan. Die naam van die gemeente word finaal vasgestel as die Niederlandisch-Reformierte Gemeinde en sou bestaan op die grondslag van die Heidelbergse Kategismus, die Nederlandse en Skotse konfessies, die liturgie van die Palz en die Jülich-Bergse kerkorde.

Kohlbrugge word in 1848 predikant van die gemeente. Omdat hy nóg in Duitsland nóg in die buiteland enige predikant kon vind wat tot sy ordening bereid was, is hy deur die ouderlinge van die gemeente, na handoplegging volgens I Timoteus 4:14 georden. Sy tweede vrou ontval hom in 1866. Hy bly in Elberfeld predikant, preek vir die laaste keer op 29 November 1874 en sterf op 5 Maart 1875. 
Die vraag kan gestel word of Kohlbrugge met hierdie optrede in Elberfeld strydig opgetree het met sy vroeëre sterk anti-seperatistiese oortuigings. Dit is nie die geval nie. Sy bedoeling met die verontruste groep wat ten tye van die eerste kontak met hom kerklik totaal vervreem en pastoraal onversorg was, was om hulle na die kerk terug te lei. Hy het steeds gehoop om predikant van die Reformierte Gemeente in Elberfeld te word (Rasker 1974:107). Eers toe ook dié deur vir hom finaal toegemaak is, het hy ander weë oorweeg. Sy gemeente in Elberfeld sien hy as noodgemeente. Hy het nooit sy gemeente as ware kerk teenoor die landskerk as valse kerk probeer stel nie (Rasker 1974:108). Hy het nooit verdere gemeentes probeer stig nie. Met predikante van die landskerk het hy goeie verhoudings gehandhaaf. Vele teoloë uit sy gemeente in Elberfeld het predikante in die kerk in Nederland en Duitsland geword. Hy het steeds hoë premie daarop gestel dat sy gemeente met koninklike goedkeuring gestig is.

$\mathrm{Na} 1850$ het gevoelens teen Kohlbrugge, mede as gevolg van die volgehoue optrede van vriende, in Nederland versag. Hy preek by geleentheid in die Domkerk in Utrecht waar hy vroeēr lidmaatskap geweier is. Hy preek ook op uitnodiging van Kuyper in die Zuiderkerk in Amsterdam. Nooit het hy 'n uitnodiging na 'n afgeskeie gemeente of vrye groepe aanvaar nie. 'n Beroep na Zoutlande bedank hy.

Kohlbrugge was ongetwyfeld 'n hoekige persoonlikheid. Maar sy teologie was van 'n krag, breedte en onkreukbaarheid waarsonder die kerk nie kan nie. Hy het met 'n kragtige ruk van die roer die aandag teruggedwing na die grondlyne van die Bybel en die Reformasie soos wat maar slegs 'n Luther en Barth voor en na hom kon doen. As Hervormer voel 'n mens jouself baie meer tuis in die gedagtewêreld van Kohlbrugge as in die teologiese nalatenskap van die ietwat skimmige figure van 'n P D Chantepie de la Saussaye, J J P Valeton en andere uit die etiese rigting (Van Wyk 1998:260).

\subsection{Kohlbrugge se teologie en invloed}

Skerp lig val ook op Kohlbrugge se teologie as sy verhouding tot die manne van die Réveil en die afskeiding van 1834 nagegaan word. Terwyl hy in 1833 in die Wuppertal vertoef het, het hy dár heelwat preekgeleentheid geniet. Soos reeds gemeld, is saam met die preek oor Romeine 7:14 nog twee van sy preke daar as Gastpredigten uitgegee. Dit word na Amsterdam gestuur waar veral dié oor Romeine 7:14 groot opskudding en verontwaardiging, veral onder die manne van die Réveil, veroorsaak. Met die verteenwoordigers uit dié rigting, en veral met Da Costa, het Kohlbrugge aanvanklik noue vriendskapsbande gehandhaaf. Dit is begryplik. Hulle het immers die besware teen die rasionalistiese en modernistiese gees van die tyd gedeel.

Die preek oor Romeine 7:14 veroorsaak egter in die kringe van die Réveil groot beroering wat mettertyd tot vervreemding tussen Kohlbrugge en dié rigting, en veral 
tussen hom en Da Costa lei. Maar hoe tragies ook al, was dié skeiding tog heeltemal begryplik en onafwendbaar. In die briefwisseling wat tussen Kohlbrugge en Da Costa volg, word dit duidelik dat 'n wêreld die manne van mekaar skei. Da Costa mis by Kohlbrugge die stuk oor die dankbaarheid (Rasker 1974:105). Hy verwyt Kohlbrugge daarvan dat hy blykbaar slegs die Christus vir ons aanvaar en nie die nuwe mens, die Christus in ons nie.

Hoewel die manne van die Réveil in prinsipiële verset teen die rasionalisme was, het hulle tog aan die vroom, bekeerde, weergebore mens 'n onbehoorlike, onbybelse staanplek gegee. Die heiligmaking word by hulle 'n geestelike groeiproses met iets van 'n Christelik-getinte evolusieleer (Loos 1948:26).

In sy verweer teen Da Costa stel Kohlbrugge dat Da Costa van die nuwe mens 'n nuwe beginsel maak, naamlik die Christus in ons. Maar dit is onskriftuurlik. Deur die nuwe geboorte is ons God se skepsels in Christus. Ons word heilig deur 'n vreemde heiligheid. Die Réveilopvatting oor heiligmaking, naamlik dat die mens wat van sonde vrygespreek is, na heiligmaking moet strewe en trapsgewyse daarin kan vorder, bestry Kohlbrugge fel. Hy bestry daarmee nie die heiligmaking nie, maar wel alle vorms van heiligingstelsels wat volgens wettiese eise en nie volgens evangeliese eise verstaan word nie (kyk Loos 1948:29). Al is ons nie vroom en heilig nie, ons Heiland is vroom en heilig. Al Christus se goedere is ons s'n. In Hom het ons alles; in ons self niks. Die Bybel weet niks van 'n nuwe beginsel nie; wel van 'n nuwe mens.

Hierdie geloofskritiese gesigspunte van die Gastpredigten van 1833 het mettertyd so allesbeheersend geword dat Kohlbrugge vanuit dié oogpunt graag die hele inhoud van sy teologie getipeer het (Haitjema 1953:130). Hy gee self die volgende drie kenmerke van sy teologie aan: Dat ek 'n mens is en niks meer nie; dat God God is; dat God God se beloftes aan my vervul. Baie van dié uitsprake van Kohlbrugge sou in die teologie van Karl Barth nuwe en selfs sterker verwoording en aktualiteit vind.

Soos met die Réveil het Kohlbrugge aanvanklik ook met die afskeiding van 1834 noue kontak gehad. Mettertyd sou hy ook met dié rigting breek en tot die mees prinsipiële kritikus daarvan ontwikkel.

Met die vernaamste leiers van die afskeiding het hy aanvanklik nou vriendskapsbande gehandhaaf: $H$ de Kock, $H$ P Scholte en A Brummelkamp. Hulle het immers teen 'n gemeenskaplike vyand, naamlik die liberalisme in kerk en teologie, te staan gekom. Dit is daarom begryplik dat van die begin af en tot so laat as in 1839 pogings aangewend is om Kohlbrugge tot die afskeiding oor te haal. Dat hy ondanks sy teleurstellings met die Nederlandse Hervormde Kerk en die feit dat hy daar nie eers lidmaatskap kon verkry nie en ondanks sy hunkering na die prediking en die kansel, die versoeking om dit by die afgeskeidenes wel verwesenlik te kry, weerstaan het, kan 
slegs verklaar word uit die feit dat hy hom teologies en kerklik baie ver van dié beweging verwyder gevoel het. Dit het gegeld, nie net van die afgeskeidenes se leer nie, maar ook van die wyse waarop die afgeskeie gemeentes erkenning gesoek en bekom het. Daardeur het hulle hulleself tot sekte gemaak en getoon. ' $U$ bestaan as sodanig is sondig', skryf hy by geleentheid aan die afgeskeie gemeentes (Loos 1948:35).

Kohlbrugge het by geleentheid bepaalde bedenkinge teen die Dordtse Leerreëls geopper (kyk Loos 1948:37). Waarom, so vra hy, is die Sinode van 1618 in die weerlegging van die remonstrante weggevoer van die vryspraak deur Christus na die leer oor die predestinasie? Op die ou end val die aksent swaarder op die uitverkore mens as op die uitverkiesende God. So kom die humanisme wat een oomblik verwerp word, die volgende oomblik weer deur 'n agterdeur die kerk en teologie binne. Die klem lê te sterk op die weergebore mens, in plaas van op dié God wat alles nuut maak.

Teen die agtergrond is dit begryplik waarom Kohlbrugge nie met die afskeiding van 1834, waarin daar soveel nawerkinge van die Nadere Reformasie gewoel het, kon saamgaan nie. Ewemin kon die manne van die afskeiding hulle met die prediking van Kohlbrugge vereenselwig. Scholte skryf 'n formele veroordeling van die preek oor Romeine 7:14 (Loos 1948:42). Aanvaarding van dié prediking sou die afgeskeies terugbring in die skoot van die Hervormde Kerk. Kohlbrugge merk by die afskeiding die aktiwiteit van die vroom vlees. Maar alle aktiwiteit van die vlees beteken vyandskap teen God. Alle reformasie van die kerk moet alleen verwag word van die Woord, die suiwer prediking van die evangelie, van die regverdiging van die goddelose deur die geloof in Christus.

Kohlbrugge was wars van alle seperatisme. Seperatisme spruit uit hoogmoed. Die Here begeer nie 'n kerk van suiwer mense nie, maar 'n kerk van sondaars, vrygespreek deur Christus. Daarom was die leer oor die vryspraak deur Christus en die gedagte aan 'n vrye kerk vir hom onversoenbaar (Loos 1948:49).

Samevattend oor die teologie van Kohlbrugge kan op hierdie stadium die volgende vier punte gestel word:

* Soos die etiese teologie, en soos Hoedemaker, het Kohlbrugge hom ferm, selfs radikaal teen twee fronte opgestel; aan die een kant teen die liberalisme van sy tyd en veral teen die selfvertroue van die Verligting; aan die ander kant teen die piëtisme en die selfvertroue van die vroom mens. Tot 1833 grens hy hom veral teen die rasionalistiese denkbeelde in kerk en teologie van sy tyd af. $\mathrm{Na} 1833$ gaan hy stilswyend daaraan verby en verset hom ewe fel teen die bevindingsvroomheid en konventikel-Christendom soos dit tot uitdrukking gekom het in afskeiding, Réveil en ortodokse teologie. Net soos Hoedemaker en Barth, laat hy die indruk van on- 
versetlikheid, onverdraagsaamheid, selfs hardheid. Maar dit was die eer van God waarvoor hy gestry het. Hy kon hom nie versoen met enige rigting, hoe vroom en Christelik ook al, wat die mens en sy dade in die plek van God se Woord stel nie. In sy lewe merk ons die krag van eensydigheid. Hy praat oor die Woord en geloof, oor sonde en genade nie anders as in paradokse nie; om sonde te sien en genade te glo; om God nie te sien nie maar God lief te hê; om verlorenheid te ervaar, maar van redding te getuig (Kohlbrugge sa:21).

Kohlbrugge se teologie het in sy eie tyd nie sterk invloed en deurwerking gehad nie. Maar sy denke in paradokse, en veral sy fundamentele kritiek op alle menslike godsdiens sou in die teologie van Karl Barth en daarna sterk verklanking en deurwerking vind. Kohlbrugge het 'n hoekige persoonlikheid en strydlustige geaardheid gehad. Maar na elke episode of fase van hierdie stryd en onbuigsame weerstand staan daar in sy lewe en teologie een helder baken uit: Die Here ons geregtigheid (Loos 1948:177).

* Kohlbrugge se teologie is teologie van die Woord. Met Woord van God bedoel hy een oomblik die hele Bybel, Ou en Nuwe Testament, dan weer die gepredikte Woord en dan weer Jesus Christus. Ook hierin is sterk ooreenstemming met die drie gestaltes van die Woord wat Barth later sou onderskei naamlik die geopenbaarde Woord, Jesus Christus, die geskrewe Woord en die gepredikte Woord (Haitjema 1964:181).

Geloof is nie allerhande menslike ervarings en handelinge nie, maar eenvoudig om vas te hou aan die Woord. Daarby handhaaf Kohlbrugge konsekwent 'n baie noue verband tussen die Woord en die werk van die Heilige Gees. Die Gees werk deur die Woord en waar die Woord is, is die Gees ook teenwoordig. Soos God aan die begin uit niks, alleen deur die Woord hemel en aarde geskep het, so skep God weer, uit niks, alleen deur die Woord, 'n nuwe mens.

* Daarmee is ons reeds in die hart van Kohlbrugge se teologie, naamlik die regverdiging, die vryspraak van goddeloses enkel op grond van God se vrye, soewereine genade. En God se genade is nooit 'n krag wat vir ons tot beskikking staan nie. Dit rus geheel en al in God se hand en daarom is dit betroubaar. Met hierdie paradokse het Kohlbrugge gestoot op die locus classicus van sowel die Lutherse as gereformeerde dogmatiek (Rasker 1974:109): God se vryheid en soewereiniteit. 'Hierin is een vaste lijn, waarin de antropologie, de christologie en de pneumatologie consequent één type, én karakter hebben. Het is alles van God en daarom alleen is het alles voor de mens' (Rasker 1974:109). 
Daarmee het Kohlbrugge in die aaklige toestande wat modernisme en rasionalisme aan die een kant en die reaksies daarop, naamlik ortodoksie en bevindelikheid aan die ander kant, in die negentiende eeuse kerk en teologie laat ontstaan het, nie net teruggekeer tot die Reformasie nie maar met forse denke en optrede die grondlyne van die Reformasie verder deurgetrek. In die teologie van Karl Barth sou hierdie grondlyne van die Reformasie verdere verwoording vind en uiteindelik die kar van die negentiende eeuse nieu-protestantisme onderstebo keer. In aansluiting by hierdie grondlyne is vir 'n eeu lank in Hervormde geledere in Suid-Afrika gestalte gegee aan 'n Bybels-Reformatoriese teologie met 'n eie karakter en stempel vir hierdie tyd en wêrelddeel. In hierdie teologie het Hervormde teoloë hulle vir die grootste deel van die twintigste eeu tuis gevoel, baie meer as in die bevindelikheids tipe teologie van die etiese rigting met as kenmerk 'n sterk drang na sinteses en 'n swak ontwikkelde kerklike bewussyn en betrokkenheid.

* Juis by Kohlbrugge, en later Hoedemaker se opvattings oor kerk en volkskerk, sou die Hervormde teologie in Suid-Afrika sterk aansluiting vind. Terwyl Hoedemaker veral die breedte van die kerk in die $\infty$ g gehad het, sien Kohlbrugge veral die diepte van die kerk raak. 'Hoedemaker had oog voor de breedte der kerk, d.i. voor den grondslag, die zij heeft in het genadeverbond Gods, voor de betekenis van den kinderdoop, voor de ontmoeting van kerk en volk bij het doopvont, voor het verbond van de nationale kerk met het volk en met de overheid (art 36 der NGB)' (Loos 1948:180).

Langs die lyn van Kohlbrugge se teologie, sê Loos, kom ons tot dieselfde sake, maar van 'n ander kant af. Kohlbrugge weet ook van antiteses maar dan totaal ander antiteses as wat die piëtisme en Kuyper later sou stel. Teenoor die piëtistiese opvatting dat tussen weergeborenes en onweergeborenes wesenlike verskil is, stel hy dat ook die weergebore mens vlees is (kyk Loos 1948:180). Teenoor die neiging om die weergeborenes saam te bring in 'n konventikel, 'n afgeskeie of vrye kerk, stel hy die solidariteit van almal wat sondaars is. Kohlbrugge wil niks weet van die regverdiging van uitverkorenes nie, maar alleen van die regverdiging van sondaars. Teenoor die seperatistiese antitese tussen gelowiges en ongelowiges stel hy skerp die antitese tussen God en mens, vlees en Gees.

Kohlbrugge het ' $n$ teensin gehad in alle pogings tot kerksuiwering deur die bymekaarbring van ware gereformeerdes of weergeborenes. Die belangrike in die kerk is dat die Woord onbelemmerd verkondig moet word. Dan kom die res vanself in orde. 
Hierdie spesifieke nuanse het in die Hervormde teologie in Suid-Afrika sterk uitdrukking gevind, onder andere in die teologiese denke van manne soos F J van Zyl. Dit is 'n geloofshouding wat alles verwag van God en God se werk, niks van die vroom mens en die mens se aktiwiteit nie. Dit is 'n berekende wending weg van die mens na die ryk Christusverkondiging van die Skrif.

Teen hierdie agtergrond kan Kohlbrugge se hartstogtelike liefde en toegeneëntheid tot die Nederlandse Hervormde Kerk begryp word; ook sy lojaliteit en trou, ondanks die afjakke wat hy van die Hervormde Kerk gekry het en ondanks al die gebreke wat hy in hierdie kerk opgemerk het. Die Hervormde Kerk was vir hom 'n kerk van sondaars wat genade ontvang het. Loos (1948:180) sien 'n noue verband tussen Kohlbrugge se prediking van die regverdiging deur die geloof en sy trou aan die Nederlandse Hervormde Kerk en die landskerk in die Rynland. Hy sien ook sterk verband tussen die oplewing van Hervormde kerklike bewussyn en 'n herontdekking van Kohlbrugge se teologie in Nederland teen die jare vyftig van hierdie eeu.

Agter die vrye kerk lê daar 'n ander teologie as agter die volkskerk.

Of de kerk volkskerk is, is niet, of althans niet in de eerste plaats, een quaestie van zielental, maar een quaestie van prediking en van pastorale praktijk. Wanneer de kerk ernst maakt met het Evangelie, d.i. met de boodschap, dat de Zoon des menschen gekomen is niet om te roepen rechtvaardigen maar zondaars tot bekeering, wanneer zij, in de vaste overtuiging, dat de liefde Gods in Christus wijd en veel omvattend is, er een ruime dooppractijk op na durft houden, wanneer zij, wetende dat het Woord vleesch werd, vrij en open - hoewel om des kruises wil altijd critisch tegenover het natuurlijke leven durft staan, dan is zij volkskerk. De Hervormde kerk is zulk een volkskerk.

(Loos 1949:181)

Die invloed wat hierdie volkskerkopvatting, soos veral ook later deur Hoedemaker onder woorde gebring, op die Nederduitsch Hervormde Kerk hier gehad het, hoef nie verder beredeneer te word nie. 'n Blik op die Kerkwet van 1951 maak dit al voldoende duidelik. Die Nederduitsch Hervormde Kerk wou nooit anders kerk wees as só nie. Die omwisseling van hierdie ryk geskakeerde en teologies gelade volkskerkbegrip tot bloot die idee van 'n etniese kerk vir Afrikaners, soos die meeste Hervormde lidmate dit vandag verstaan en gebruik, is 'n tragiese ontwikkeling wat die verdere gebruik van die begrip om iets wesenliks or die kerk te sê, bykanś onmoontlik maak. 
Loos (1948:182) dui ook aan dat 'n herontdekking van die teologie van Kohlbrugge in die eerste helfte van hierdie eeu 'n wesenlike bydrae gelewer het om die rigtingstryd in die Nederlandse Hervormde Kerk te versag. Immers, waar die erkenning kom dat ook die vroom mens en dié se beginsels vlees is, en dat alleen die Woord van God heilig en onaantasbaar is, daar word ook die betreklikheid van rigtings en beginsels in die kerk besef. Daar is lidmaat en predikant nie meer woordvoerders van 'n party nie, maar lidmaat van die kerk van die Here en dienaars van die Woord. Is dit miskien die miskenning van dié absoluutheid van die Woord wat ook in die Nederduitsch Hervormde Kerk die afgelope jare tekens van 'n rigtingstryd laat opvlam het?

Soos vir die Nederlandse Hervormde Kerk het Kohlbrugge ook vir sy nuwe vaderland hartstogtelike liefde gekoester. Nogtans het hy nie gehuiwer om fundamentele teologiese kritiek te lewer teen 'n vereenselwiging van die nasionale saak en die monargie met God se bedoelings vir land en volk nie (Rasker 1974:112). Dit blyk onder andere uit sy preke tydens die oorlog van 1870 . Hy dien as blywende voorbeeld daarvan dat liefde vir volk en vaderland nie op sigself sondig is of tot burgerlike godsdiens of volksteologie hoef te lei soos wat soveel Afrikaanse en ook Hervormde teoloë oor die afgelope jare gevrees het nie. In die stryd van die Bekennende Kirche teen die nasionaal-sosialisme was die Niederlandisch-Reformierte Gemeinde in Elberfeld 'n sterk steunpunt (Rasker 1974:112).

Or die unieke en selfs radikale nuanses waarmee Kohlbrugge die heiligmaking beklee het, is reeds een en ander gesê na aanleiding van sy preek oor Romeine 7:14. Gelowiges het hulle lewe in niks anders as in God se genade nie. Maar ook die feit dat die gelowige daaraan vashou, is geen menslike moontlikheid nie maar alleen God se werk. Kohlbrugge verwerp die gedagte dat die heiligmaking 'n proses is, dus die heiligwording van die mens behels. God doen nie halwe werk nie. As God heilig maak, doen God dit volkome. Die heiligmaking, net soos die vryspraak van sonde, is geheel en al die werk van Christus.

Verskeie teoloë het in die teologie van Barth nawerkinge van die werk van Kohlbrugge bespeur. $\mathrm{O}$ Noordmans is 'n voorbeeld, alhoewel hy vanuit sy eie staanplek in die etiese teologie, nie baie positief oor sowel Barth as Kohlbrugge oordeel nie. Hy skryf in 1930 reeds dat daar op die tydstip 'n teologiese rigting die aandag trek wat sterk aan Kohlbrugge herinner, naamlik dié van Karl Barth (Noordmans 1930:24). Die teologie van Barth is filosofies geintoneer en georiënteer, dié van Kohlbrugge teologies. Afgesien van meerdere verskille is daar sterk verwantskap tussen dié twee teoloë.

Deur die invloed van Barth in die besonder en die dialektiese teologie in die algemeen, het die teologie van Kohlbrugge isolasie ontkom (Haitjema 1953:142). Die studie van die dialektiese teologie het oral belangstelling gewek vir die eensame figuur van 
Kohlbrugge wat in sy tyd dieselfde stryd gestry het as wat vir Barth en sy medestanders ter harte gegaan het (Loos 1948:179).

Ter afsluiting oor Kohlbrugge word 'n woord van W Balke (1992:64) aangehaal:

Het wezenlijke van de gereformeerde traditie heeft hij duidelijk vertolkt, maar Luther heeft hij zijn leven lang het meest en het liefst gelezen. Dat aparte heeft zijn leven niet gemakkelijk gemaakt; de vorige eeuw heeft met hem amper raad geweten. Voor die Lutherse was hij te onverdraagsaam, in het nogal piëtistische Elberfeld was hij voor de grote kerk te resoluut, voor het Réveil te passief, voor de hervormde kerk te verontrustend, maar voor de Afscheiding weer te ruim, te sterk verbonden met de hele kerk en het hele volk.

As die spiritualiteit van Da Costa en Kohlbrugge naas mekaar gelê word, val die tydgebondenheid van 'n figuur soos dié van Da Costa op. Daarnaas spring die groot en blywende betekenis van die teologie van Kohlbrugge in die oog. Hy het in hom meer van die gees van alle eeue (Balke 1992:73). Sy herontdekking van die betekenis van die brief aan die Romeine plaas hom op een lyn met Augustinus, Luther, Calvyn ... en Barth.

\section{PHILIPPUS JACOBUS HOEDEMAKER 1839-1910}

Soos Kohlbrugge, was ook P J Hoedemaker 'n eensame, dikwels onbegrepe mens en denker. Ook sy lewe was gekenmerk deur onrus, voortdurende stryd en konflik. Die voortdurende losmaak van homself uit die greep van groepe en partye wat hom vir hulle saak wou gebruik, sy selfstandigheid asook die felle en radikale toon en trant waarin hy dikwels die stryd voer, herinner sterk aan sowel Kohlbrugge as Barth. Hy het magtige rigtings van sy tyd aangedurf waaronder die etiese, die modernisme, die Doleansie en later ook die konfessioneles. In dié proses het hy te staan gekom teen formidabele figure soos dié van Abraham Kuyper, 'n man wat nie net predikant en hoogleraar aan 'n universiteit asook eerste minister van sy land geword het nie, maar in sy leeftyd ook 'n politieke party, 'n universiteit en 'n kerk op die been gebring het. Van Kuyper het Hoedemaker 'n keer gesê: 'Hy is my meerdere, maar ek is anders.' Met die bree, Bybelse denke van Hoedemaker oor die kerk, wars van alle partyvorming en seperatisme, toon Hervormde teologie in Suid-Afrika sterk verwantskap. Die denke van Hoedemaker oor die kerk het in die tyd van die ontstaan van die Nederlandse Hervormde Kerkorde van 1951 sterk invloed uitgeoefen veral deur Haitjema se beweging vir kerkherstel (kyk Kromsigt 1932:10). En die invloed wat dié gebeure en denke in 
Suid-Afrika op die Nederduitsch Hervormde Kerk se eie kerkwet van 1951 gehad het, kan nie misken of verswyg word nie.

Hoedemaker verwys in sy werk selde indien ooit na Kohlbrugge. Dieselfde geld van Barth ten opsigte van Hoedemaker en Kohlbrugge. Maar in die teologie van al drie word karaktertrekke herkenbaar wat sterk verwantskap vertoon met wat in die Hervormde Kerk hier bekend geraak het as 'n Bybels-Reformatoriese teologie en houding oor kerk en geloof.

\subsection{Hoogte- en dieptepunte}

Philippus Jacobus Hoedemaker is in 1839 in Utrecht gebore. Sy pa het daar tot die afgeskeie kerk van ds H P Scholte behoort. Sy ma was nooit hart en siel by hierdie kerk betrokke nie en het innerlik met die Nederlandse Hervormde Kerk verbonde gebly. Oor die doop van haar seun in die afgeskeie kerk was sy ongelukkig. Sy het geglo dat op haar gebed haar seun nog die volle raad van God sou gaan verkondig en vir die vaderlandse kerk, die Nederlandse Hervormde Kerk, tot besondere seën sou word. Haar gebed sou langs wonderlike weë bewaarheid word. So het Hoedemaker sy latere sterk anti-seperatistiese houding en teologie met moedersmelk ingekry (Kromsigt 1932:4).

In 1851 vertrek die gesin, soos baie afgeskeies in dié tyd, na Amerika. Hoedemaker studeer daar en ook in Duitsland teologie. Terug in Nederland onderneem hy om op 21 September 1862 die oggenddiens in die Oosterkerk in Amsterdam te hou en die aanddiens in die afgeskeie kerk op die Keisersgracht. Toe die afgeskeie gemeente die situasie verneem, versoek hulle dat Hoedemaker hom aan die oggenddiens moes onttrek. Hy kies egter vir die diens in die Oosterkerk en wys die uitnodiging vir die aanddiens van die hand. Dit word 'n keuse vir sy lewe.

Hy sit sy teologiese studies voort en promoveer onder $J$ J van Oosterzee met 'n proefskrif getitel Het probleem der vrijheid en het theistisch Godsbegrip. Vanaf 1868 tot $\mathbf{1 8 7 3}$ is hy predikant te Veenendaal. Hier leef hy in noue kontak met Kuyper asook met J H Gunning (jr) en D Chantepie de la Saussaye. Na aanleiding van sy begrip vir en vriendskap met laasgenoemde twee, asook oënskynlike ooreenkomste in denke oor die toestande in die kerk in dié tyd, is daar al gepraat van 'n etiese periode in Hoedemaker se lewe. Dit is egter 'n vergissing. Reeds in sy Veenendaalse periode tree sy fundamentele verskille met die etiese teologie aan die lig. Hy voel by De la Saussaye 'n té positiewe verwagting en waardering van die modernisme aan. Terselfdertyd deel hy nie die cordrewe vrees van De la Saussaye vir die ortodoksie nie. Die optimisme wat De la Saussaye vir die modernisme koester, koester Hoedemaker vir die ou vaderlandse kerk en die Gereformeerde kerkvolk. De la Saussaye se opvatting was dat die kerk onherstelbaar krank is. Hoedemaker het dus van meet af aan baie sterker belang- 
stelling in die kerkkwessie en kerkherstel gehad as De la Suassaye. Dié gebrek aan betrokkenheid in die nood van die kerk, sou 'n blywende kenmerk van die etiese teologie word.

Met Gunning het Hoedemaker uit die staanspoor verskil ten opsigte van die waardering vir die historiese kritiek. Reeds in 1872 verset hy hom teen voorstelle van Kuyper en De la Saussaye om die kerk maar op independentistiese wyse te laat uiteengaan in gemeentes volgens die drie of vier groot hoofrigtings. Dit het gebeur onder invloed van die vrye kerkidee wat reeds op dié stadium sterk veld gewen het (Kromsigt 1932:8).

Die grondstelling van die etiese teologie, naamlik dat die waarheid eties is, het Hoedemaker nie ingesien nie en in elk geval nie aanvaar nie. Teenoor die opvatting van die etiese rigting dat die verhouding van leer en lewe wederkerig is, stel Hoedemaker dat die waarheid, ook sonder dat dit die nodige invloed het op hart en wandel, steeds waarheid van God is. Daarom, sê Scheers (1939:41) dat van 'n etiese periode by Hoedemaker nie anders nie as slegs tussen aanhalingstekens gepraat moet word. Van werklike innerlike verwantskap met die etiese teologie was daar by Hoedemaker nooit sprake nie.

In Veenendaal begin Hoedemaker reeds werk aan die uitgawe van sy Handboek voor het onderwijs in het Oude Testament (Kromsigt 1932:8). Die Ou Testament sou hom sy lewe lank intens boei. Nie die weergeboorte nie, maar die verbond het teenoor doperse indiwidualisme en independentisme die grondslag van sy prediking en teologie, veral sy kerkopvatting, geword. Teenoor alle gedagtes aan splitsing en deling sou hy lewenslank bly opkom vir die volk in geheel, dus ook die volkskerk.

Vanaf 1873 tot 1876 is Hoedemaker predikant in Rotterdam. Hy spreek hom al sterker uit teen alle vorms van partyskap en vir die historiese Gereformeerde volkskerk. Hy dien hierna as predikant in Amsterdam totdat hy in 1880 saam met Kuyper en F L Rutgers aangestel word as die eerste hoogleraars om die teologiese fakulteit aan die pasgestigte Vrye Universiteit te beman. Hy doseer onder andere Ou Testament, Etiek en Praktiese Teologie. Die aand voor die opening van die universiteit lewer Hoedemaker die amptelike wydingsrede na aanleiding van 1 Samuel 13:19-22. Hy sien die opening van die nuwe universiteit as 'n deur van hoop waar die Gereformeerde teologie op eie erf kan woon en kan saamwoon met die wetenskap op grond van die ooreenkoms dat beide hulle sou onderwerp aan dieselfde mag, die hoogste en die ewige (Hoedemaker 1880:24).

Hoedemaker het hom met hart en siel aan die saak van die Vrye Universiteit gewy. Hy kom egter in al sterker opposisie teen die afskeidingsbeginsels van Kuyper. As hy merk hoe die universiteit al meer gebruik word om kant te kies teen die Hervormde 
Kerk en ten gunste van die Doleansiebeweging, raak sy posisie onhoudbaar. Hy bly vurig bid vir die reformasie van die kerk, en die herstel van die verskeurde gemeenskap. Al sou die kerk hom loslaat, hy laat die kerk nooit los nie. Na lang aarseling besluit hy om nie die kerklike kongres in Januarie 1887 by te woon nie. Dié kongres sou 'n oproep doen om die juk van die sinodale hiërargie af te werp en sou só die stoot gee aan die uittog van die Dolerendes uit die kerk. In 'n brosjure verantwoord hy hom volledig oor waarom hy nie na die kongres gaan nie. Blote opposisie wil hy nie daar gaan wees nie. Terselfdertyd egter wil hy op geen wyse solidêr wees met wat hy as onbybels, verkeerd en verderflik beskou nie (Hoedemaker 1887:5). Die kongres, so konkludeer hy, bedoel die organisasie van geesverwante. Maar dit is die wese van die sektarisme. Wat hy bedoel, is die behoud van die kerk (kyk Abma \& De Bruijn 1989:21).

Hoedemaker dien in 1887 sy bedanking aan die Vrye Universiteit in en word weer predikant, nou in Nijland, vanaf 1888 tot 1890 . Vanaf 1890 dien hy vir 'n tweede periode as predikant in Amsterdam. Hy aanvaar emeritaat in 1909 en sterf in 1910.

\subsection{Hoedemaker en die kerk}

In hierdie latere fase van sy lewe lewer Hoedemaker steeds 'n vrugbare reeks publikasies. Daarin val die lig veral op sy siening oor die kerk. Hy beleef veel vreugde in die toenadering tussen hom en J H Gunning (jr), veral rondom die stryd vir kerkherstel.

In 'n vorige artikel (Van Wyk 1990:497-512) is uitgebreide aandag aan Hoedemaker se beskouing oor die kerk gegee. Hier word kortliks enkele gedagtes bygevoeg. Hoedemaker word meermale verdink van fundamentalisme. Daarop word later teruggekom. Maar 'n ander verdenking teen hom is dat hy voorstander was van 'n belydeniskerk en in sy denke or Skrif en belydenis konfessionalisties was. Daar blyk egter uit Hoedemaker se publikasies geen grond vir dié verdenkings nie. In 1897 verskyn een van sy mees bekendgeworde brosjures: Heel de Kerk en heel het volk! Daarin skryf hy dat die geneesmiddel vir die krankheid van die kerk nie is om mekaar te verdryf en te verdring nie, maar eenvoudig om belydende kerk te wees, 'n kerk wat as uitdrukking van die eenheid van die kerk nie sonder belydenis is nie, maar wel dié belydenis ondersoek, handhaaf, hernu (Hoedemaker 1897:33). In dieselfde brosjure verskyn 'n brief aan die bestuur van die Konfessionele Vereniging waarin hy hom verantwoord oor sy bedanking uit dié Vereniging. Hy onttrek hom aan die groep, so skryf hy, om by die waarheid wat God hom laat sien het, te bly (Hoedemaker 1897:45). Maar hy wil ewemin behoort tot dié kringe wat onder invloed verkeer van die Doleansie of in onderskeid van ander groepe in die kerk graag bekendstaan as Gereformeerdes. Hy wil tot 'n Gereformeerde kerk behoort; tot 'n gereformeerde party, nooit. Hy is eenvoudig ' $n$ mens wat die belydenis sal bly beaam solank hy nie oortuig is dat dit op hierdie of 
daardie punt van die Woord waaraan hy hom gebonde ag, afwyk nie (Hoedemaker 1897:40).

Hoedemaker het steeds gewys op die verkeerde beginsel wat in Artikel II van die Algemeen Reglement verwoord was. Daar is die handhawing van die leer wel uitdruklik as plig aan alle besture opgedra. Maar daar is geen weg aangetoon waarlangs iemand wat van die leer, dit is van die belydenis van die kerk verskil, op die Woord van God 'n beroep kan doen nie. Daardeur word van die belydenis juis iets gemaak wat dit nie is nie, naamlik 'n eenmalige formulering as onveranderlike grootheid waaraan niks verander mag word nie (kyk Kromsigt 1932:14). Maar so 'n gedagte is vir hom ontoelaatbaar in 'n Protestantse Kerk wat die laaste beroep op die Woord van God altyd moet oophou. Die gevolg van dié verkeerde beginsel in Artikel II was juis praktiese leervrykeid, want nou het individue vir hulleself vryhede veroorloof volgens wat reg is in hulle eie oë sonder dat leergeskille langs Skriftuurlike weg en op broederlike wyse getoets en beslis kon word. Hierdie finale beroep op die Woord, was vir Hoedemaker van prinsipiële gewig (Kromsigt 1932:14). Hy wou dat weë geopen word om die belydenis aan te vul, desnoods te wysig en te verbeter, met die oog op vrae van die dag. In nog ' $n$ brosjure, Het uitgangspunt der Reformatie, skryf hy dat elke reformasie begin met ' $n$ terugblik op die verlede, die punt van uitgang, die oorsprong; nie om daar te bly nie, maar om te sien hoe diep ons geval het en hoe hoog God ons wil bring - daar lê die grond van ons hoop (Hoedemaker 1903:12).

Ook hierin merk hy by die Dolerendes ' $n$ dwaling, naamlik om die belydenis wat niks meer is nie as ' $n$ tydelike uitdrukking van die waarheid wat die kerk in die gang van die eeue onder leiding van die Heilige Gees uit die Woord van God geleer het, as iets selfstandigs te beskou, onafhanklik van die Woord.

Alle partyskap is uit die bose, skryf Hoedemaker in 1885 vlak voor die Doleansie (kyk Kromsigt 1932:12). Dit was hierdie hartgrondige afkeer van alle vorme van partyskap in die kerk wat hom ferm oortuig het dat die Skriftuurlike weg om geskille te besleg, weer geopen moes word. Dit beteken dat die ampte soos deur Christus ingestel, in hulle regmatige funksie herstel moes word, bevry van die onskriftuurlike bestuursmag van 1816 wat as 'n voogdy oor hulle gestel was. Ook die vergaderings, van ampsdraers moes herstel word. Dit was 'n radikaal ander weg as wat Kuyper gekies het. Kuyper was bereid om die bestuursmag desnoods te behou, solank daar van onder af 'n kragtige Gereformeerde party gevorm word wat die dinge geleidelik, en indien nodig met geweld, na sy hand kon verander. So was Kuyper se reorganisasieprogram geheel en al op die party-wese gegrond (Kromsigt 1932:11).

Daarmee het ons aangekom by die kern van die konflik tussen Kuyper en Hoedemaker, maar ook in die hart van Hoedemaker se kerkbeskouing. Hy dink oor die kerk 
vanuit die verbond, terwyl Kuyper vanuit 'n doperse indiwidualisme en independentisme oor die kerk dink en praat (Kromsigt 1932:11). Hierdie verskil het deurgewerk by die geestelike en kerklike nakomelinge van Kuyper en Hoedemaker. Die neiging tot afskeiding is in die geskiedenis van die Gereformeerde Kerke herhaal, egter nie in die Hervormde tradisie wat in die lyn van Hoedemaker se denke oor die kerk voortgeplant is nie. ' $n$ Ander opmerklike verskynsel, is dat by die nakomelinge van Hoedemaker nie die neiging bestaan om hulle in die politieke en maatskaplike lewe in Christelike partye en verenigings te organiseer nie.

Hoedemaker gaan in sy prediking, asook in sy kerk- en staatsbeskouing uit van die verbondsgedagte waartoe sy groot voorliefde vir die Ou Testament hom steeds stimuleer en van waaruit hy by sy volksbegrip kom. Hoedemaker self het nie die begrip volkskerk baie gebruik nie, waarskynlik vanweë die karikatuur wat die Sinode van 1886 daarvan gemaak het, naamlik dat alles wat aan religieuse lewe onder die volk gis, in die kerk nágis en ook dat 'n volkskerk alle lede van 'n volk moet omvat. Dié karikatuur het Hoedemaker ontmasker en fel bestry. Al wat die sinode hier gedoen het, is om sy eie organisasie met 'n volkskerk te vereenselwig (kyk Scheers 1939:191). 'n Kerk waarin alles, Arianisme, Pelagianisme, Remonstrantisme, modernisme en ateïsme gis, 'n volkskerk wat so ruim is dat dit die hele volk kan omvat, is nie meer kerk nie.

Wat bedoel Hoedemaker met die volkskerk? Nie die karikature van die sinode soos verwerp deur Kuyper nie, maar hy bedoel die kerk, en in dié geval dan die Nederlandse Hervormde Kerk soos dit nou saamgeweef is met die geskiedenis van die Nederlandse volk en gegrond is in die verbond soos beseël in die doop. (kyk Van Wyk 1990: 509). Op nydige beskimpings wat dié wat in die Nederlandse Hervormde Kerk agtergebly het, vergelyk het met 'Jan Rap en sy maat' of hulle beskryf het as 'n wilde vermenging van etici, onverskilliges en modernes, het Hoedemaker gereageer: Hulle almal is deur die doop in die verbond van God opgeneem, kinders van die verbond, huisgenote van die geloof. Enige reorganisasie van die kerk moet daarop ingestel wees om die kerk weer waarlik belydende kerk in die midde van die volkslewe te maak. Die reformasie van die kerk moet nie net vir diegene ten goede kom wat reeds tot die waarheid gekom het nie, maar vir almal wat in die verbond van God inbegrepe is. Daarmee het Hoedemaker lynreg teenoor Kuyper te staan gekom, vir wie die kern van sy kerkbegrip in die weergeboorte gesetel het. Vir Kuyper is die kerk daar waar die ware belyers is; vir Hoedemaker daar waar Woord en sakramente bedien word.

Waarom het Hoedemaker en baie van sy geesgenote in die Hervormde Kerk gebly? Nie uit konserwatisme, onkunde of slapheid nie, maar uit beginsel en omdat hy oortuig was dat dié kerk, ondanks diep verval, steeds kerk van Jesus Christus was. Die weg tot kerkherstel moes nie gesoek word in die rigting van 'n ortodokse sinode nie. So 'n 
sinode sou dan waarskynlik 'n etiese sinode moes wees. Meermale het Hoedemaker van dié moontlikheid gesê: 'Mag God ons daarvan behoed!' Hy en baie ander het in die Hervormde Kerk gebly om te stry en te reformeer; omdat die Woord van God dit eis. Afskeiding is dwaling, sonde voor God. Die Doleansie het die nood van die kerk nie verlig nie, maar dit verdiep. Oor waarom soveel saam met hom in die Hervormde Kerk agtergebly het, skryf Hoedemaker dat baie hulle nog nie bewustelik daarvan rekenskap gegee het nie. Dit lê egter in die hart en ervaring van dié mense wat nie uit konserwatisme of welke motief ook al nie, maar uit 'n wesenlike teologiese intuïsie die versoeking tot afskeiding weerstaan het (Van Wyk 1990:508).

Dit is nie net deur sy volkskerkbegrip dat Hoedemaker baie sterk invloed in SuidAfrika in die Nederduitsch Hervormde Kerk bly uitoefen het, tot in die kerkwet van 1951 en lank daarna nie. Hoedemaker het ook die teologiese en kerklike intuïsie van die meeste lidmate van die Nederlandse Hervormde Kerk wat in dié kerk agtergebly het, vertolk en beliggaam. Ons kan dit probeer omskryf as 'n intuisie weg van partyskap en afskeiding, terselfdertyd oop, en met passie en bewoënheid vervul na die hele volk en al die kinders van die volk onder wie die kerk in 'n bepaalde tyd en land leef en werk en verkondig. In die Nederduitsch Hervormde Kerk hier het dit deurgewerk in houdings soos byvoorbeeld die oop uitnodiging na die Nagmaal en 'n ontspanne verhouding oor kanselruil. Dit is jammer dat al hierdie diepsinnige teologiese inhoude van die volkskerk by min Hervormde lidmate nog bekend is. Dit is verdring deur ' $n$ volkskerkidee wat slegs as etniese kerk, kerk vir die blanke Afrikaner verstaan word.

\subsection{Hoedemaker en die verstaan en uitleg van die Bybel}

Was Hoedemaker in sy verstaan en uitleg van die Bybel fundamentalisties? Immers, so fel as wat hy hom teen die bestuursorganisasie van Koning Willem I uit die jaar 1816 verset het, net so fel het hy hom mettertyd teen Kuyper gekeer, maar ook teen die modernisme en teen die histories-kritiese ondersoek van die Bybel wat hy as 'n vorm van Skrifkritiek ervaar het. Dit is waarskynlik hierdie laasgenoemde faset van Hoedemaker se teologie wat veroorsaak dat navorsers soos Loader die enorme invloed wat Hoedemaker origens op Hervormde teologie in Suid-Afrika gehad het, negeer of betwyfel. Want die restultate van die histories-kritiese ondersoek is steeds met vrymoedigheid in die Hervormde teologie in Suid-Afrika gebruik en verdiskonteer.

Ook oor die saak van Hoedemaker se Skrifbeskouing is in 'n vorige artikel in Hervormde Teologiese Studies gehandel (Van Wyk 1991:1069-1087). Om Hoedemaker se teologie en felheid van baie van sy uitsprake reg te kan beoordeel, moet die omstandighede in die kerk en teologie van sy tyd in berekening gebring word. Breë lae van die kerklike bevolking was deurdrenk van die gees van verligting en rewolusie. Bin- 
ding aan die kerk se belydenis is op allerlei wyses afgewater en die kernwaarhede van die Christelike geloof is deur prominente teoloë ontken en verloën. Soos Kohlbrugge voor hom en Barth na hom, het Hoedemaker ervaar dat slegs deur 'n kragtige ruk van die roer teen dié stroom ingekom sou kon word.

Hy bestry nie maar net die historiese kritiek nie, maar lê steeds die agtergronde van waaruit dit voortgekom het, bloot. Daar moes noodwendig tot onjuiste resultate gekom word, omdat uitgegaan is van 'n ongeoorloofde wetenskaplike hipotese, naamlik dat, soos by Wellhausen en Kuenen, die hoëre uit die laere voortkom, dus van die evolusieteorie. Volgens Kuenen moes die gebou van Israel se geskiedenis afgebreek en van voor af opgebou word. Wellhausen het die werk van sy voorgangers verder deurgetrek en in die Pentateug vier bronne onderskei. So word daar gekom tot 'n radikale rekonstruksie van die geskiedenis van Israel. Die onderskeie bronne J, E, D en P verteenwoordig drie stadia in die ontwikkeling van die godsdiens in Israel. Daarin is die Wet nie die uitgangspunt nie, maar die resultaat van die geestelike ontwikkeling van Israel (God met ons: Over de aard van het Schriftgezag 1981:35).

In sy skerp reaksie hierop gaan dit vir Hoedemaker nie om die Mosaiese oorsprong van die Wet as sodanig nie, maar om die Goddelike oorsprong van die Heilige Skrif. Dit gaan vir hom om baie meer as net die tyd van bepaalde uitsprake in die Bybel. As die ontkenning van die Mosaiese oorsprong van die Pentateug die Goddelike gesag en oorsprong van die Skrif in gedrang bring, is dit wel deeglik van belang. Hy sien die ontwikkeling van Israel nie as 'n ontwikkeling van laer na hoër nie, maar juis andersom. Die volmaakte staan aan die begin.

Dit val op dat Hoedemaker baie feller op die etiese Ou-Testamentici J J P Valeton jr en G Wildeboer reageer as op Kuenen en Wellhausen (Hoedemaker 1895). Valeton en Wildeboer eis volgens hom ten onregte die vertroue van die kerk op. Hulle opvattings is baie gevaarliker as dié van die moderniste al gebruik hulle ook die woorde geloof, bekering, weergeboorte hoe dikwels. Al wat hulle doen, is om geleidelik deur te voer wat die modernes konsekwent en rewolusionêr gedoen het. Hoedemaker hou vol dat dit nie moontlik is om soos Valeton en Wildeboer, die uitgangspunt, metode en resultate van die histories-kritiese ondersoek te aanvaar en terselfdertyd vas te hou aan die Christus van die Skrifte nie (kyk Scheers 1939:172). Juis in diê etiese teoloë se aanvaarding van die historiese kritiek sien Hoedemaker gevaar omdat, terwyl hulle bekendstaan as ortodoks en regsinnig, hulle soms selfs verder gaan as die modernes. Dit mislei gemeentelede om te meen iemand is ortodoks bloot omdat hy anti-modern is.

Hoedemaker hou vas aan die eenheid van die Skrif. Dié eenheid is 'n eenheid in Christus. Daarmee bedoel hy nie dat Christus oral in tekste in die Ou Testament ingelees of gesoek moet word nie. Hy betrek die hele Ou Testament op Christus. Die hele Ou Testament is voorbereiding op die openbaring in Christus. 
Hoedemaker verwerp die meganiese inspirasie van die Skrif. Daar moet in die uitleg van die Skrif voluit rekening gehou word met die unieke karakter van die Bybel, maar ook met die menslike kant daarvan (kyk Van Wyk 1991:1080). Hy het al die menslike faktore wat werksaam was in die totstandkoming van die Bybel, asook die onskatbare waarde van die histories-kritiese navorsing vir die beter verstaan van die Skrif, voluit erken.

As uitgangspunt vir sy benadering tot die Skrif neem hy die belydenis. Die wetenskap is nie neutraal nie, die ewolusionisme ook nie. Waarom, so vra hy (Scheers 1939:179), mag Kuenen, Wellhausen en ander modernes vanuit hulle invalshoek aan die werk gaan, maar hy moet sy werk wildvreemd aanpak asof hy nie belydenis van geloof afgelê het nie? Word die belydenis nie as uitgangspunt gebruik nie, beteken dit dat elkeen daar kan vind wat hy graag wil vind.

Maar elke keer as Hoedemaker sy uitgangspunt in die belydenis verklaar, grens hy hom ferm af teen enige gedagte aan belydenisdwang. Ons mag die belydenis nooit daar plaas waar Rome met sy onfeilbare uitleg sy formuliere plaas nie, naamlik bokant die Heilige Skrif. Die uitleg van die Skrif mag nooit aan menslike geskrifte gebind word nie. Hier is hoogstens sprake van 'n voorwaardelike gebondenheid. In die laaste instansie is die eksegese uitsluitend gebind aan die Woord. In die uitleg van die Bybel mag ons van die rede gebruikmaak mits die rede gebruik word as instrument en nie as bron nie. Die historiese kritiek, soos hy dit by die modernes van sy tyd leer, is 'n poging om die geskiedenis van Israel uit die mens te verklaar.

Daar kan met vrymoedigheid toegegee word dat bepaalde denkbeelde van Hoedemaker oor verstaan en uitleg van die Skrif vandag verouderd en onbruikbaar is. Fundamentalisties was hy egter nie. Sy opvattings moet ontleed en waardeer word teen die agtergrond van sy tyd. Terwyl die modernisme as vrug van rasionalisme en die rewolusionêre tydgees verwoesting in kerk en teologie gesaai het, was teoloë self lamgelê deur verregaande konsessies aan die rede, magteloos om prinsipiële kritiek te lewer. Hoedemaker, as een van weinige uitsonderings, het dié prinsipiële kritiek met krag en oortuiging aangedurf. Die teologiese aanpak en veral die werkwyses van Kuyper het hy verag. Hy het 'n ander, 'n kerklike weg gekies - met onnoembare stryd en eensaamheid as gevolg. Eers vanaf die dertigerjare van hierdie eeu toe 'n kragtige beweging tot reorganisasie met nuwe klem op die kerk op dreef gekom het, is sy teologiese denke werklik ontdek en nuut waardeer. Sedert ongeveer 1930 is die stryd vir kerkherstel in voetspoor van Hoedemaker kragtig deur Th L Haitjema voortgedra.

Hoedemaker se verset was daarteen gerig dat in sy tyd die Bybel nie meer die stem van God tot die mens was nie, maar dat net menslike stemme oor God gehoor is. Hy staan ook nie alleen in sy oordeel oor die etiese teologie en die histories-kritiese meto- 
des en resultate van sy tyd nie. H Berkhof (1955:270) sê dat talle van die jonger etiese teoloë onder suigkrag van die naturalistiese denke en die historiese kritiek in subjektiwistiese en indiwidualistiese vaarwaters beland het.

Vrymoedige aanwending van die resultate van die histories-kritiese ondersoek en ryk geskakeerde verdere ontwikkelings daarin, is vandag deel van ons teologie. Negering daarvan sou dwaasheid wees. Maar daar moet ook erken word dat alles in die histories-kritiese navorsing van destyds nie goed en vir die kerk tot seën was nie. Daar het tempering en ewewig gekom - waarin die meedoënlose kritiek van Hoedemaker 'n belangrike rol gespeel het.

Opsommend oor Hoedemaker enkele laaste gedagtes.

* Die wydheid en oorspronklikheid, lewendigheid en veelsydigheid van sy denke kan teruggevoer word na sy Bybelse ingesteldheid en sy enorme kennis van die Bybel, veral die Ou Testament. Daardeur kon hy Skrif met Skrif vergelyk. Vir hom was die Woord werklik 'n lamp vir die voet en lig op die pad.

* Sy voorbeeld van liefde vir en trou aan die Hervormde Kerk as Kerk van die Reformasie het 'n groot deel van die Nederlandse Hervormde Kerk se lidmate oortuig om nie met die Doleansie saam te gaan nie. Sy klassiek geworde woorde oor 'Jan Rap en sy maat' met wie hy verkies om in die Hervormde Kerk agter te bly, het baie oortuig dat daar in die kerk plek vir die 'skare' moes bly, sonder dat die karakter van die kerk daarmee ingeboet word (kyk Scheers 1939:281). Hy het die teologiese gronde verskaf om in die 'groot' kerk te bly. Ons herken hier baie van ons eie intuïsie, aanvoelinge en hartstogte vir die kerk van die Here.

\section{KARL BARTH 1886 - 1968}

As in hierdie artikel gepraat word van 'n lyn vanaf Kohlbrugge na Hoedemaker na Barth, word nie bedoel dat dié drie teoloë bewustelik by mekaar aangesluit het of op mekaar se gedagtes voortgebou het nie. Soos reeds vermeld, kom verwysings na Kohlbrugge in Hoedemaker se werk skaars voor, so ook in Barth se werk na Hoedemaker en Kohlbrugge. Wat wel daarmee bedoel word, is dat al drie dié teoloē in die krisisse van hulle tyd teologieë met sterk gemeenskaplike en tog selfstandige trekke ontwikkel het: Om God God te laat wees; terug na die Reformasie en die Bybel; 'n Bybels-Reformatoriese teologie wat die kerk kerk wil laat wees - losgeruk uit die inpalming van partye en ideologieë; 'n vashou aan die dialektiese, paradokse spanning in die verhouding van God en mens, tyd en ewigheid; teenoor alle rasionalistiese en subjektiwistiese ont- 
sporinge van die agtiende en negentiende eeu in, 'n Bybels-gefundeerde denke oor sonde en genade, vryspraak en die ware heiligmaking; 'n teologie van die Woord.

Nadat die Eerste Wêreldoorlog die bankrotskap van die outonome mens so fel ontmasker het, was dit veral Karl Barth wat die moed geopenbaar het om die hinkery op twee gedagtes prys te gee en weer radikaal vanuit die Woord te dink (vgl Berkhof 1955:273). Daarin het hy nie net teruggekeer na Luther en Calvyn nie, maar ook na oorspronklike figure soos Kohlbrugge en Kierkegaard wat konsekwent teen die tydgees opgeroei het en met profetiese krag alle menslike eiewaarde naas die Woord neergeslaan het. Met hierdie Bybelse, Reformatoriese wortels en karaktertrekke van kerk en teologie toon die Hervormde teologie in Suid-Afrika sterk verwantskap; en nie met 'n etiese teologie waarvan Berkhof (1955:270) skryf: "'n Sametreffing van die bonatuurlike, die goddelike met die natuurlike, in die mens. Daarmee word bedoel dat die openbaring aansluit by die diepste behoeftes van die mens, soos dit in die gewete geopenbaar word'.

Karl Barth is op 10 Mei in Basel gebore. Sy vader en grootvader was albei predikante, eersgenoemde ook hoogleraar. Van Barth self word gesê dat hy intensief geleef het, geestig, humoristies en tot ' $n$ lewenswyse gevorm is waar, op 'n teologiese basis kultuur, beskawing en geleerdheid tot eenheid saamgesnoer is (Kupisch 1971:19). Op skool het hy 'n teësin in wiskunde en rekenkunde geopenbaar. In natuurwetenskaplike vakke het hy swak gevaar. Topprestasies is behaal in tale, veral Duits, geskiedenis en letterkunde. Hy studeer teologie in Berlyn en kom sterk onder die invloed van Julius Kaftan, Adolf von Harnack en Herman Gunkel. Hy studeer verder in Tübingen en dan, teen die wens van sy vader in, in Marburg, bakermat van die Neo-Kantianisme. Sy pa wou deurgaans liewer sien dat sy seun aan 'n positief-Bybelse inrigting studeer as om, soos hy dit gesien het, die bree weg van teologiese liberalisme te gaan. In Marburg word Barth die meeste beindruk deur Wilhelm Herrmann. Teen die einde van sy studie betuig hy homself volledig in harmonie met die moderne teologiese insigte soos hy dit in Marburg verwerf het, waarvan religieuse indiwidualisme en historiese relatiwisme die hoofkenmerke was.

Barth word in 1911 predikant in Safenwil, 'n gemeente bestaande uit boere en fabriekswerkers. Hy kom van naby in aanraking met die sosiale vraagstuk en ook onder die invloed van die religieus-sosialistiese beweging. Tot sy eie groot verrassing word hy in 1921 in 'n nuwe en buitengewone leerstoel vir Calvinistiese teologie in Göttingen benoem. Dit word gevolg deur 'n professoraat in Münster vanaf 1925 en in Bonn vanaf 1930. In Desember 1934 word hy as politiek-onbetroubare amptenaar uit sy betrekking ontslaan. Die werklike rede was sy aanvanklike weiering om die eed van trou aan Adolf Hitler af te lê. Na verskeie aanbiedinge besluit hy om terug te keer na die uni- 
versiteit van sy ou geboortestad, Basel. Hy ontvang emeritaat in 1961 en sterf in Basel op 10 Desember 1968. Barth is as dorpspredikant tot hoogleraar benoem. Hy het nooit 'n doktorale eksamen afgelê nie. Naas talle ander toekennings is elf ere-doktorsgrade in die jare na die Tweede Wêreldoorlog aan hom toegeken.

\subsection{Tydens die Eerste Wêreldoorlog}

Op Sondag, 3 Augustus 1914 kom die fatale nuus: Duitse troepe het die Belgiese grens oorgesteek. Die Eerste Wêreldoorlog was 'n werklikheid. Europese nasionalisme word deur historici aangegee as een van die grootste corsake van die oorlog (Blenk 1988:15). Duitsland was omring deur vyande. Daarom was die oorlog 'n heilige Krieg. Tydens die Eerste Wêreldoorlog is die Godsvraag nog nie gestel nie. Dit sou eers in die Tweede Wêreldoorlog kom. Maar nie in 1914 nie. Gott unserer Văter sou aan Duitsland die oorwinning gee. Der Deutsche Gott word God in 'n publikasie genoem (Blenk 1988:18). Die teoloog, Adolf von Harnack, stel Keiser Wilhelm II se oorlogsoproep op.

Barth kon nie woorde vind om sy skok uit te spreek nie. Erger as die skending van die Belgiese neutraliteit was vir hom die verklaring van drie en negentig intellektueles wat hulle in die openbaar met die keiser se oorlogspolitiek identifiseer. Onder die name was bykans al sy leermeesters uit die liberale teologie. Daarmee gaan 'n wêreld van eksegese, etiek, dogmatiek en prediking wat hy tot op die stadium as geloofwaardig beskou het, vir hom verlore (vgl Blenk 1988:23). Hy begin nou twyfel, nie net aan die Duitse teologie nie, maar ook aan die Europese sosialisme. Vir die meer regsinnige sienings van sy vader, wat intussen plotseling oorlede is, ontwikkel hy nou groter waardering. Marburg en die Duitse kultuur verloor vir hom alle glans. Op die beslissende moment blyk die vrysinnige Protestantisme niks beter te wees as die ortodoksie nie. Hy beland in ' $n$ teologiese lugleegte.

Dan suggereer sy lewenslange vriend Eduard Thurneysen: Met Schleiermacher kan ons nie meer nie; wat ons nodig het, is 'n geheel ander teologiese basis. Barth begin die Bybel lees soos hy dit nog nooit tevore gedoen het nie, ook die Romeinebrief (Bromiley 1981:154). En hy ontdek 'n nuwe wêreld: Nie die ware gedagtes van die mense oor God nie, maar die ware gedagtes van God, die gansandere, oor die mense (Blenk 1988:26).

Dit was nie om politieke redes of vanweẽ sy Switserse neutraliteit dat Barth nie met die 'idees van 1914' kon saamgaan nie. As jong teoloog merk hy met ontsetting hoe die Christendom in dié bewoe tyd ontpop as meeloper in die tydgees. Die absolute van die evangelie word eenvoudig tot nadere kennisgewing opgeskort. Intussen word 'n Germaanse oorlogsteologie, Christelik versier, van krag verklaar (kyk Kupisch 
1971:10). Ontnugter en teleurgesteld dring die vraag hom in sy gemeente van boere en fabriekswerkers al sterker aan Barth op: Wat moet ek preek? Uit sy briefwisseling met Thurneysen in dié tyd blyk dat daar in die pastorie in Safenwil 'n groot herontdekking kom van wat eintlik met die term 'Woord van God' bedoel word (Kupisch 1971:11). So was dit die nood van die prediking wat sou lei tot die eerste uitgawe van sy kommentaar op die Romeinebrief. Tydens ' $n$ konferensie van religieuse sosialiste in Tambach in September 1919 veroorsaak Barth opskudding toe hy die openbaring van God in Christus in die middelpunt stel. Hy ontmasker genadeloos alle vorms van Christendom-met-' $n$-verbindingstrepie as pure menslike poging om tot 'n eie vormgewing van die wêreld te kom (Kupisch 1971:51).

Met sy verhuising van Safenwil na Göttingen was die tweede uitgawe van die Römerbrief voltooi. Die radikale kentering, in die eerste uitgawe aangekondig, word nou nog meer konsekwent en dialekties deurgetrek. Teenoor die histories-relatiwistiese, konserwatief-ortodokse asook die piêtisties-romantiese gaan dit vir hom uitsluitend om duideliker verkondiging van die heilige God wat alleen in Jesus Christus deur God self geopenbaar word. Nie mense met hulle wense, verlangens en behoeftes nie, maar God se wil en gebod soos dit in kruis en opstanding tot openbaring gekom het, moet weer onderwerp van die teologie en opdrag aan die kerk word. Stap vir stap en doelbewus neem hy afskeid van al die sterk invloede uit sy studiejare: Religieuse sosialisme, nieu-protestantse vrysinnigheid en liberalisme. Hy wil kom tot 'n radikale herbesinning op die oorspronklike gehalte van die Christelike boodskap. Hy wil erns maak met die Godheid van God en die werklikheid van Christus. Deur dit te doen, wil hy tot 'n besliste afwysing kom van alle sekulêre of sakrale verafgoding van die skepsel (Kupisch 1971:54). Die taak van die teologie is dieselfde as die taak van die prediking: Om die Woord van Christus in sigself op te neem en deur te gee. Reeds op hierdie stadium is van Barth se teologie algemeen gepraat as die dialektiese teologie of teologie van die krisis.

Barth het die gesag van die Reformatoriese teologie en veral van Luther erken, maar het nooit gemeen dat onder teologie van die Woord 'n nuwe soort Lutheranisme verstaan moes word nie. Hy gaan volkome sy eie weg en wou dat wat die Reformatore ontdek het, in sy tyd nuwe geldigheid kry. Hy sou hom nooit in enige vorm van konfessionalisme laat inbind nie. Die dialektiese teologie het nooit 'n skool gevorm nie. Van al sy geesgenote sou hy hom mettertyd losmaak: Gogarten, Brunner, Bultmann (Bromiley 1981:148).

Barth het hom onvermoeid besig gehou met die vraag na die taak van die teologie. En ewe onvermoeid was sy antwoord: Dié taak is die Woord van God wat die predikant in die kerk moet verkondig en wat die dosent in die lesingsaal moet leer. As 
mense moet ons dus oor God praat. -Maar dit kan nie, want oor God kan God alleen praat. Dit beteken die absolute neerlaag van die teoloog. God is God en volkome anders as alles wat menslik is, ook volkome anders as alle menslike kultuur en religie. God kan alleen in God se menswording, soos die Heilige Skrif daarvan getuig, gehoor word. Die geopenbaarde Woord van God, deur mensemond gespreek, word die waarheid van God. Kansel en kateder is die plekke waar, op verskillende wyses, hierdie waarheid verkondig word.

Oor sy siening van en houding tot die filosofie was Barth baie uitgesproke. Hy was geen vyand van die filosofie as sodanig nie, maar aan Bultmann skryf hy dat hy die eksistensiefilosofie nie werklik verstaan nie en dit nie ernstig neem nie, ook nie as bindende aksioom vir teologiese denke nie (Bromiley 1981:105). Ten opsigte van enige eise van filosofiese kant het hy ernstige reserwe. Hy ervaar dat tussen hom en Bultmann nie 'n gemeenskaplike sleutel is om met mekaar te praat en mekaar te verstaan nie.

\subsection{Rondom die Tweede Wêreldoorlog}

In 'n sekere sin het sedert ongeveer 1930 'n volgende fase in Barth se lewe en teologiese ontwikkeling gekom. Dit gaan gepaard met sy benoeming in Bonn, die ontstaan van sy hoofwerk, die Kirchliche Dogmatik, asook sy betrokkenheid in die Duitse kerkstryd.

Barth het met besorgdheid die segetog van die nasionaal-sosialistiese geloofsbeweging van Duitse Christene asook Hitler se verregaande ingryping in kerksake gadegeslaan. In dié tyd verskyn van hom 'n brosjure Theologische Existenz heute! Daarin stel hy dat hy ook nou, midde in die storm van gebeure, sal trag om met sy studente teologie en alleen maar teologie te beoefen; miskien wel met 'n effense stemverheffing, maar tog sonder direkte standpuntinname (Kupisch 1971:95).

Barth se houding is met skok en ongeloof begroet. Opnuut kom hy alleen te staan. Hy neem in dié tyd afskeid van sy vriende Friedrich Gogarten en Emil Brunner by die tydskrif Zwischen den Zeiten. Ongeag sy skerp afwysing van die Duitse Christene is sy voorneme om maar net teologie te bly beoefen, as teleurstellend ervaar. Maar ook na die kant van die owerheid het verhoudinge meer gespanne geraak. Immers, hy stel ferm dat kerk en teologie die natuurlike grens is van elke staat, ook die outoritêre staat. Kerk en teologie moet die volk, ook die volk wat leef in 'n outoritêre staat, bly bedien met die Woord; die Woord waarvan die inhoud is: vergewing van sonde, opstanding en ewige lewe.

Die aanvanklike losse verset van belydende Christene teen die Duitse Christenbeweging het geleidelik gegroei en gekonsolideer tot by die ryksinode van Barmen op 30 en 31 Mei 1934. 'n Kommissie, bestaande uit Barth, Thomas Breit en Hans Asmus- 
sen het vir dié sinode 'n teologiese verklaring opgestel wat algemeen aanvaar is. Die inhoud was saamgevat in die eerste stelling wat ook die basis van die volgende vyf was. Dit het soos volg gelui:

Joh 10:6; Joh 10:1.9 - Jesus Christus, soos die Heilige Skrif van Hom getuig, is die Een Woord van God waarna ons moet luister, waarop ons in lewe en dood moet vertrou en waaraan ons moet gehoorsaam.

Ons verwerp die valse leer, as sou die kerk as bron van haar verkondiging buite en naas hierdie een Woord van God ook nog ander feite, magte, figure en waarhede as Gods- openbaring kan en moet erken.

(Kupisch 1971:102)

Hierdie eerste stelling was 'n samevatting van alles waarvoor en waarteen Barth sedert die Romerbrief gestry het. Dit het alle teologie, gegrond op natuur en geskiedenis as bron vir die openbare erediens, afgewys. Dié proses het volgens Kupisch (1971: 103) by Schleiermacher begin en het by die teoloë wat in 1933 gepraat het van die groot uur van God, geëindig. Dit het van die volksaard as skeppingsorde 'n bestanddeel van die eerste geloofsartikel gemaak. Barth self het van hierdie stelling gesê dat dit 'n lyn getrek het onder 'n eeu-oue geskiedenis van Protestants teologiese onduidelikheid en verwarring.

\section{VERDERE BESINNING NODIG}

A G van Aarde deel ook die mening dat etiese invloed speurbaar is in die agtergrond van die Nederduitsch Hervormde Kerk se teologie. Hy skryf dat J H J A Greyvenstein, eerste teologiese professor van die Hervormde Kerk, in Utrecht, Nederland tydens sy studiejare, nie net die Nederlandse Hervormde Kerk goed leer ken het nie, maar ook die etiese teologie (Van Aarde 1992:149). Hy het daar onder andere sterk onder die invloed van J J P Valeton gekom en dit 'lyk ... of Greyvenstein bewustelik 'n eksponent van die etiese teologie was' (Van Aarde 1992:154). Van Aarde (1993:5) skryf ook dat die etiese teologie die Nederlandse antisipasie was van die dialektiese teologie wat in Duitsland ontstaan het.

In die lig van wat in hierdie artikel tot dusver en ook in 'n vorige (Van Wyk 1998: 245-263) betoog is, word gevra vir grondige herbesinning oor Loader, Van Aarde en andere se siening oor die etiese teologie en die invloed daarvan. Voorlopig word hier nogeens gestel dat die etiese teologie wesensvreemd is aan die teologiese eie-aardigheid 
van die Nederduitsch Hervormde Kerk en in werklikheid geen invloed daarop kon gehad het nie. Dit is die teologiese denke en werk van Kohlbrugge, later Hoedemaker en uiteindelik Barth wat die Hervormde opleiding en teologie in sy ontwikkeling tot volkome selfstandigheid sou stempel. Sowel Kohlbrugge as Hoedemaker het in die negentiende eeu elkeen op sy eie wyse en in sy eie tyd 'n eensame maar manmoedige stryd gevoer vir die herstel en gesondheid van die kerk en geloof en die behoud van die grondwaarhede van die Reformatoriese teologie. In dié proses is terselfdertyd 'n sterk wal opgewerp teen die negentiende-eeuse nieu-Protestantisme met die liberale, modernistiese, maar ook neo-Calvinistiese, ortodokse en seperatistiese tendense daarvan. Weinig word gevind van 'n bewustelike rol wat etiese teoloë, met die vermelde uitsondering van J H Gunning jr, daarin gespeel het. Dit sou uiteindelik Karl Barth wees wat sou regkry om die kar van dié teologie onderstebo te keer.

Die vernaamste etiese teoloë het 'n swak kerklike bewussyn geopenbaar; wel 'n sterk drang na sintese tussen filosofie en teologie; piëtisties-bevindelik maar met min hartstog vir die nood van die kerk. Nederlandse teoloë soos Hoedemaker en later Haitjema, Van Niftrik, Van Ruler en Berkhof, wie se invloed in die Nederduitsch Hervormde Kerk algemeen erken en aanvaar word, se teologie en denke adem 'n ander gees as dié van die etici. Min waardering vir die etiese rigting word by dié teoloë gevind. Oor die onhoudbaarheid van teorieẽ wat verband lê tussen die etiese en die dialektiese teologie, is in 'n vorige artikel breedvoerig gehandel (Van Wyk 1998:7, 14). In dieselfde artikel is aangetoon dat die etiese teologie se opvatting dat die waarheid eties is, nie verwant is aan Brunner se beskouing van waarheid as ontmoeting nie. By die etiese teoloë was dié uitspraak 'n blote vlag waaronder vreemde ladings soos indiwidualisme, subjektiwisme en bevindelikheid gevaar het. As daar dan by Greyvenstein sprake is van etiese invloed, lê dit in Ritschliaanse sin van die opbou van die sedelik hoogstaande persoonlikheid (Van Zyl 1974:187). In die Hervormde teologie in Suid-Afrika het dít nie verdere deurwerking gevind nie.

Hier word volstaan met die oortuiging dat die Nederduitsch Hervormde Kerk se teologiese inhoude die raakste gestempel word as Bybels-Reformatories en in aansluiting by Kohlbrugge, Hoedemaker en Barth verder genuanseer word as teologie van die Woord; oorheersende klem op die vryspraak deur die geloof; heiligmaking, nie as werk en prestasie van die mens nie, maar as daad van God; ontsag vir die dialektiese, paradokse spanning tussen God en mens, ewigheid en tyd; 'n sterk ontwikkelde kerklike bewussyn en intuïsie, antiseperatisties, waaraan die begrip volkskerk uitdrukking gee; respek vir en handhawing van die belydenis as normale lewensruimte vir die kerk, maar sonder om te verval in belydenisdwang en konfessionalisme. 


\section{Literatuurverwysings}

Abma, G \& De Bruijn, J 1989. Hoedemaker herdacht. Baarn: Ten Have.

Balke, W 1992. Heel het Woord en heel de Kerk. Kampen: De Groot Goudriaan.

Berkhof, H 1955. Geschiedenis der Kerk. Nijkerk: Callenbach.

Blenk, C 1988. Kerk- en wêreldgeschiedenis van de 20e Eeu. Kampen: Kok.

Bromiley, G W 1981. Karl Barth - Rudolf Bultmann, Letters 1922-1966. Grand Rapids Eerdmans.

God met ons: Over de aard van het Schriftgezag 1981. Special Kerkinformatie, Nummer 113, Gereformeerde Kerken (Nederland). Utrecht: Tijl Libertas.

Haitjema, Th L 1953. De richtingen in de Nederlandse Hervormde Kerk. Wageningen: $H$ Veenman \& zonen.

- 1964. De nieuwere geschiedenis van Nederlands Kerk der Hervorming. 'sGravenhage: Boeckencentrum.

Hoedemaker, Ph J 1880. Wijdingsrede bij de opening der Vrije Universiteit op Gereformeerde grondslag. Amsterdam: Höveker \& Zoon.

- 1887. Waarom ik geen deel neem aan het kerkelijk congres. Amsterdam: Wormser.

- 1895. Als verleiders en nochtans waarachtigen: Een woord van verweer tegen prof dr J J P Valeton jr. Leiden: Daamen.

- 1897. Heel de Kerk en heel het volk. Sneek: Campen.

- 1903. Het uitgangspunt der Reformatie. Amsterdam: HAUM.

- 1908. De nood ons opgelegd. Amsterdam: B van der Land.

Kohlbrugge, H F S a. De eenvoudige Heidelberger. Franeker: T Wever.

Kromsigt, P J 1932. Wie was dr Hoedemaker? Wageningen: H Veenman \& Zonen.

Kupisch, K 1972. Karl Barth. Baarn: Ten Have.

Loader, J A 1996. 'n Hervormde tradisie as heelmiddel. HTS 52, 566-589.

Loos, J 1948. De theologie van Kohlbrugge. Amsterdam: Uitgeversmaatschappij Holland.

Noordmans, O 1930. Geestelijke perspectieven. Amsterdam: Paris.

Rasker, A J 1974. De Nederlandse Hervormde Kerk vanaf 1795. Kampen: Kok.

Scheers, G Ph 1939. Philippus Jacobus Hoedemaker. Wageningen: Veenman \& Zonen.

Van Aarde, A G 1992. Die eerste treë op weg na 'n kritiese en historiese NuweTestamentiese-Wetenskap aan die Universiteit van Pretoria: Die bydrae van J H J A Greyvenstein, hoogleraar 1917-1945. HTS 48, 137-158.

1993. Paradigmaveranderinge: Wat word daarmee bedoel? Die Hervormer, $86 / 16$.

1995. Kerk en teologie oppad na die 3e millenium: Gedagtes oor die kontekstualisering van die dialektiese teologie in 'n plurale samelewing. HTS 51, 39-64. 
Van Wyk, D J C 1990. P J Hoedemaker: Wat ék bedoel, is die behoud van die Kerk. HTS 46, 497-512.

1991. P J Hoedemaker: Teoloog en kerkman. HTS 47, 1069-1087.

1998. Wortels en agtergronde van Hervormde teologie en kerkwees in SuidAfrika. HTS 54, 245-263. 